Rev. Inst. Flor. v. 29 n. 2 p. $239-251$ dez. 2017

http://dx.doi.org/10.24278/2178-5031.201729208

ISSN impresso 0103-2674/on-line 2178-5031

\title{
PHYSICAL-MECHANICAL WOOD PROPERTIES OF Myracrodruon urundeuva IN HOMOGENEOUS PLANTING'
}

\author{
PROPRIEDADES FÍSICO-MECÂNICAS DA MADEIRA DE \\ Myracrodruon urundeuva EM PLANTIO HOMOGÊNEO
}

\author{
Andressa KELLER ${ }^{2}$; Adriano Wagner BALLARIN²; \\ Miguel Luiz Menezes FREITAS 3 ; Antonio Carlos Scatena ZANATTO $^{3}$; \\ Eduardo Luiz LONGUI ${ }^{3,4}$
}

\begin{abstract}
As a result of its high density and durability, wood of Myracrodruon urundeuva (aroeira) is highly valued, and its exploitation in Brazilian primary forests has been prohibited by law since 1991. One way to maintain this status and, at the same time, supply the increased demand for this wood is through the establishment of plantations. Therefore, the knowledge of $M$. urundeuva wood properties in plantations with young trees is essential. Thus, we evaluated we evaluated some physical and mechanical properties of wood from 20-year-old M. urundeuva (aroeira) twelve trees in a homogenous plantation. Basic density was $770 \mathrm{~kg} \mathrm{~m}^{-3}$ and apparent density was $984 \mathrm{~kg} \mathrm{~m}^{-3}$. The anisotropy coefficient of 1.69 is considered regular, indicating that wood can be used in the manufacture of fine furniture, frames, boats, musical instruments, sports equipment or flooring. The wood presented good mechanical behavior, with an average strength for parallel compression of $53.84 \mathrm{MPa}$, MOE of $12632 \mathrm{MPa}$ and MOR of $123.58 \mathrm{MPa}$. The wood was identified as class 40, thus showing potential for use in medium-sized structures and construction. Basic density and apparent density correlated positively with compression parallel to the grain and MOR. Wood quality, a positive characteristic, added to good technology, even in young trees, shows that values of physical and mechanical properties are suitable for various uses when compared to the same values of older trees based on specialized literature. Our results confirmed that this homogeneous planting was adequate to obtain M. urundeuva wood with such quality.
\end{abstract}

Keywords: aroeira; physical and mechanical properties of wood; wood technological potential.

\footnotetext{
${ }^{1}$ Recebido para análise em 01.06.17. Aceito para publicação em 14.12.17.

2Universidade Estadual Paulista "Júlio de Mesquita Filho" - UNESP, Faculdade de Ciências Agrônomicas, Av. Universitária, 3780, Altos do Paraíso, 18610-034, Botucatu, SP, Brazil.

${ }^{3}$ Instituto Florestal, Rua do Horto, 931, 02377-000, São Paulo, SP, Brazil.

${ }^{4}$ Corresponding author: Eduardo Luiz Longui - edulongui@gmail.com
} 
RESUMO - Devido à alta densidade e durabilidade, a madeira de Myracrodruon urundeuva (aroeira) é muito valorizada, e sua exploração em florestas nativas brasileiras é proibida desde 1991. O estabelecimento de plantações é uma maneira de manter essa situação e, ao mesmo tempo, fornecer o aumento da demanda por essa madeira. Assim, o conhecimento das propriedades da madeira de $M$. urundeuva em plantações com árvores jovens é essencial. Portanto, avaliamos algumas propriedades físicas e mecânicas da madeira em árvores de $M$. urundeuva com 20 anos em uma plantação homogênea. A densidade básica foi $770 \mathrm{~kg} \mathrm{~m}^{-3}$ e a densidade aparente foi $984 \mathrm{~kg} \mathrm{~m}^{-3}$. O coeficiente de anisotropia de 1,69 é considerado normal, indicando que a madeira pode ser utilizada na fabricação de móveis finos, quadros, barcos, instrumentos musicais, equipamentos esportivos, pisos etc. A madeira apresentou bom comportamento mecânico, com uma resistência média à compressão paralela de 53,84 MPa, MOE de $12632 \mathrm{MPa}$ e MOR de 123,58 MPa. A madeira foi classificada na classe C40, apresentando potencial para uso em estruturas e na construção civil. A densidade básica e densidade aparente se relacionaram positivamente com a compressão paralela às fibras e com o MOR. Um aspecto positivo é a qualificação de madeira, com bom potencial tecnológico, mesmo em árvores jovens, mostrando que os valores das propriedades físicas e mecânicas foram adequados para vários usos, quando comparados com os valores de árvores mais velhas com base na literatura. O plantio homogêneo foi adequado para obter madeira M. urundeuva com qualidade.

Palavras-chave: aroeira; propriedades físicas e mecânicas da madeira; potencial tecnológico da madeira.

\section{INTRODUCTION}

In recent years, the forest sector has gained increasing recognition owing to the importance and contribution of planted forests to the country's sustainable development. Indeed, forest plantations have promoted changes in regional and local economies, particularly those that were previously based on extractivism, an activity that has degraded vast regions of native forest and subsistence agriculture. Thus, planted forests play important roles, such as reduction of pressure on native forests, reuse of land degraded by agriculture, carbon sequestration, soil and water protection, greater homogeneity of forest products and development of forestry machinery optimizing aspects of wood production (Nahuz, 2013).

Plantations should be designed to meet these market requirements and needs, and the wood of plantation species must have characteristics that are equivalent or higher to those previously used and derived from the exploitation of native forests. Properties vary among species; therefore, when selecting wood for a particular use, physical and mechanical requirements must be considered to guarantee that the wood will perform adequately. This analysis is very important, especially in tropical countries, with great biodiversity, considering the variety and the number of forest timber species (Nahuz, 2013).

In the present study, we investigated the wood of Myracrodruon urundeuva Allemão (Anacardiaceae). According to Silva-Luz and Pirani (2017), a native, but not endemic, Brazilian species, which presents geographic distribution in all regions of Brazil in the biomes of Caatinga, Cerrado and Atlantic Forest. As a result of its high density and durability, wood of M. urundeuva is highly valued and can be used as lumber in civil construction, flooring, furniture and turned parts, as well as external construction, such as small bridges, posts, stands, corrals and railway sleepers (Lorenzi, 2002). It was the favorite wood for making fences in the interior of Brazil (Heringer and Ferreira, 1973), and it is still being used in rural areas. According to Nogueira (2010), this wood of São Paulo state presents the greatest durability. 
Exploitation of M. urundeuva in Brazilian primary forests has been prohibited by law since 1991. The use of its wood can only be exploited by means of a Sustainable Forest Management Plan and by a project previously approved by Instituto Brasileiro do Meio Ambiente e dos Recursos Naturais Renováveis - IBAMA (IBAMA, 2017). In this context, the study of practices that make it feasible to plant exotic and native species, such as M. urundeuva, should be encouraged. Such practices will contribute to the preservation of natural ecosystems, reinforce the laws that prevent predatory exploitation, and generate social and economic benefits, thus allowing the fulfillment of market requirements regarding potential species, taking into account the sustainability.

$M$. urundeuva presents slow to moderate growth, reaching annual increment of $5.50 \mathrm{~m}^{3}$. ha ${ }^{-1}$. year ${ }^{-1}$, and for best results in trunk form, planting in full sunlight is not recommended, while mixed planting with a fast-growth pioneer species has been proposed (Carvalho, 2003).

Apart from these proposals, the knowledge of $M$. urundeuva wood properties in plantations with young trees is scarce. Therefore, we aimed to determine some physical and mechanical properties of this species in a homogeneous planting in the belief that the outcome would provide knowledge for the potential use of young wood and preserve remnants of native forest without impeding exploitation in commercial plantations, thus meeting market demands. To accomplish this, we adopted a simplified characterization, determining retractibility, compression parallel to grain, modulus of elasticity (MOE) and modulus of rupture (MOR), as recommended by standard of the American Society for Testing and Materials - ASTM D143-94 (ASTM, 2007).

\section{MATERIAL AND METHODS}

\subsection{Planting Area and Sampling}

The planting was established at a spacing of $3 \times 2 \mathrm{~m}$ at the Luiz Antônio Experimental Station, Luiz Antônio City, São Paulo (21 ${ }^{\circ} 40^{\prime}$ S, $47^{\circ} 49^{\prime} \mathrm{W}$, elevation $550 \mathrm{~m})$. The average annual rainfall is $1,365 \mathrm{~mm}$ over oxisols or sandy textured soils. Climate is Aw in the Köppen-Geiger classification (Centro de Pesquisas Meteorológicas e Climáticas Aplicadas à Agricultura - CEPAGRI, 2017). In February 2011, we collected 12 trees (Table 1), about 20 years old, and from each tree, a $\log$ (1 meter in length) was cut at the region immediately below the breast height. From logs, central blocks were cut, and from these blocks, we cut four specimens with cross section of $50 \times 50 \mathrm{~mm}^{2}$ (Figure 1).

Table 1. Dendrometric data of Myracrodruon urundeuva trees. $\mathrm{DBH}=$ diameter at breast height (1.3 $\mathrm{m}$ from the ground).

Tabela 1. Dados dendrométricos das árvores de Myracrodruon urundeuva. $\mathrm{DAP}=$ diâmetro à altura do peito (1,3 m do solo).

\begin{tabular}{ccc}
\hline Tree & Height $(\mathrm{m})$ & DBH $(\mathrm{cm})$ \\
\hline 1 & 18.6 & 28 \\
2 & 18.1 & 23 \\
3 & 19.0 & 26 \\
4 & 20.1 & 28 \\
5 & 19.0 & 25 \\
6 & 19.5 & 20 \\
7 & 17.8 & 22 \\
8 & 18.0 & 19 \\
9 & 19.9 & 27 \\
10 & 18.6 & 21 \\
11 & 16.2 & 20 \\
12 & 19.1 & 20 \\
\hline Mean & 18.6 & 23.2 \\
\hline
\end{tabular}




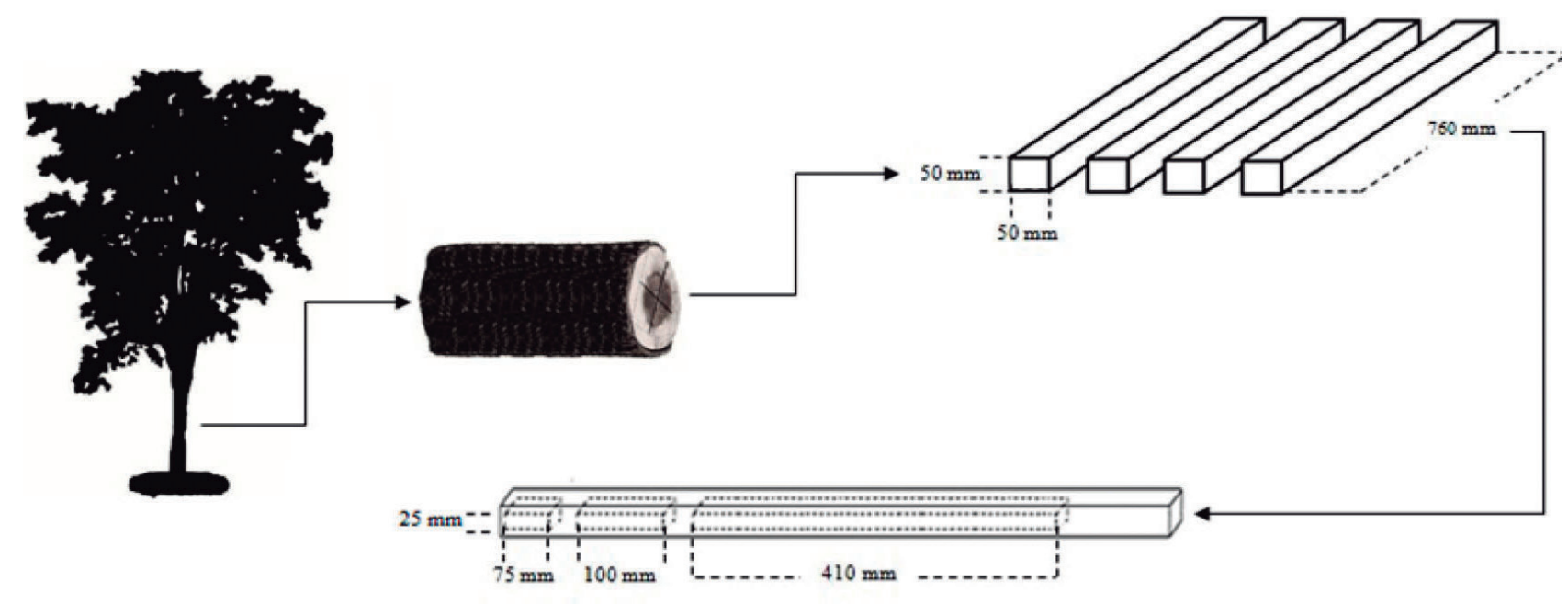

Figure 1. Schematic representation of a sample cutting for physical and mechanical tests of Myracrodruon urundeuva wood.

Figura 1. Representação esquemática do corte de uma amostra para os ensaios físicos e mecânicos.

Specimens were conditioned to equilibrium in a climate-controlled room under $65 \%$ of relative humidity and $21{ }^{\circ} \mathrm{C}$ (approximately $12 \%$ to $14 \%$ EMC). After acclimatization, specimens in nominal dimension were prepared according to the ASTM D 143 secondary method (ASTM, 2007), owing to the impossibility of obtaining clear specimens 50 by $50 \mathrm{~mm}$.

The physical and mechanical properties evaluated were as follows: basic density; apparent density at EMC; longitudinal, radial, tangential and volumetric shrinkage; strength in compression parallel to the grain; modulus of elasticity (MOE) and modulus of rupture (MOR). Mechanical tests were performed in a computer-controlled $300 \mathrm{kN}$ eletromechanical testing machine. All the variables of mechanical tests were adopted according to ASTM D 143 (ASTM, 2007). Initial results of strength and elastic properties (modulus of elasticity) were corrected to the EMC (12\%) using a conversion coefficient of $3 \%$ (of variation per $1 \%$ of $\mathrm{MC}$ variation) for strength properties and $2 \%$ for elastic properties.
The characteristic 5-percentile value of each strength property was estimated according to the simplified expression (Eq. 1), as defined by the Brazilian standard NBR 7190 (Associação Brasileira de Normas Técnicas - ABNT, 1997; Eufrade Júnior et al., 2015), in order to determine structural classification of wood in strength classes, those being hardwoods from $\mathrm{C} 20$ to C60 (Table 2), according to NBR 7190 (ABNT, 1997).

$$
\sigma_{k}=\left(2 \times \frac{\sigma_{1}+\sigma_{2}+\ldots+\sigma_{\frac{n}{2}-1}}{\frac{n}{2}-1}-\sigma_{\frac{n}{2}}\right) \times 1,1
$$

Eq. 1

where $\sigma_{k}$ is the characteristic value of strength of the wood to the test considered, and $n$ is the number of specimens.

\section{RESULTS AND DISCUSSION}

The values of apparent density and mechanical properties were corrected for the reference humidity of $12 \%$ (Table 3 ). 
KELLER, A. et al. Wood properties of Myracrodruon urundeuva.

Table 2. Strength classes and characteristic values for hardwoods at $12 \%$ m.c., according to NBR 7190.

Tabela 2. Classes de resistência e valores característicos para as madeiras de eudicotiledôneas a 12\% de teor de umidade, de acordo com a NBR 7190.

\begin{tabular}{llllll}
\hline \multicolumn{5}{c}{ Hardwoods } \\
\hline Classes & $\mathrm{f}_{\mathrm{c} 0, \mathrm{k}}(\mathrm{MPa})$ & $\mathrm{f}_{\mathrm{v0,k}}(\mathrm{MPa})$ & $\mathrm{E}_{\mathrm{c} 0, \mathrm{~m}}(\mathrm{MPa})$ & $\rho_{\mathrm{bas}}\left(\mathrm{g} . \mathrm{cm}^{-3}\right)$ & $\rho_{12}\left(\mathrm{~g} . \mathrm{cm}^{-3}\right)$ \\
\hline C20 & 20 & 4 & 9500 & 0.500 & 0.650 \\
C30 & 30 & 5 & 14,500 & 0.650 & 0.800 \\
C40 & 40 & 6 & 19,500 & 0.750 & 0.950 \\
C60 & 60 & 8 & 24,500 & 0.800 & 1.000 \\
\hline
\end{tabular}

$\mathrm{f}_{\mathrm{c} 0, \mathrm{k}}=$ compression parallel to the grain; $\mathrm{f}_{\mathrm{v} 0, \mathrm{k}}=$ shear parallel to the grain; $\mathrm{E}_{\mathrm{c} 0 \mathrm{~m}}=$ modulus of elasticity (in compression parallel to grain; mean value); $\rho_{\text {bas }}=$ basic density; $\rho_{12}=$ apparent density at $12 \%$ moisture content (mass and volume at $12 \% \mathrm{MC})$.

$\mathrm{f}_{\mathrm{c} 0, \mathrm{k}}=$ compressão paralela às fibras; $\mathrm{f}_{\mathrm{v} 0, \mathrm{k}}=$ cisalhamento paralelo às fibras; $\mathrm{E}_{\mathrm{c} 0, \mathrm{~m}}=$ módulo de elasticidade (na compressão paralela às fibras; valor médio); $\rho_{\text {bas }}=$ densidade básica; $\rho_{12}=$ densidade aparente a $12 \%$ de teor de umidade (massa e volume a $12 \%$ de teor de umidade).

Table 3. Physical and mechanical properties and failure types of 20-year-old Myracrodruon urundeuva wood.

Tabela 3. Propriedades físicas e mecânicas e os tipos de ruptura da madeira de Myracrodruon urundeuva aos 20 anos de idade.

\begin{tabular}{cccccccc}
\hline Sample & $\rho_{12}^{(1)}$ & $\rho_{\text {bas }}^{(2)}$ & $\mathrm{f}_{\mathrm{cc}}^{(3)}$ & $\mathrm{Ftc}^{(4)}$ & $\mathrm{MOE}^{(5)}$ & $\mathrm{MOR}^{(6)}$ & $\mathrm{Ftr}^{(7)}$ \\
\hline 1 & 968 & 759 & 51.77 & ws & 13280 & 131.96 & cgt \\
2 & 899 & 711 & 39.01 & ws & 11947 & 118.07 & cgt \\
3 & 830 & 662 & 34.64 & ws & 11376 & 87.69 & cgt \\
4 & 1162 & 891 & 75.30 & ws & 13028 & 145.33 & cgt \\
5 & 924 & 729 & 56.85 & ws & 11259 & 109.28 & cgt \\
6 & 895 & 708 & 45.64 & ws & 10843 & 92.16 & cgt \\
7 & 1104 & 852 & 66.91 & c & 11234 & 125.79 & cgt \\
8 & 933 & 735 & 54.71 & ws & 11285 & 120.16 & cgt \\
9 & 1143 & 879 & 65.40 & ws & 9564 & 118.37 & cgt \\
10 & 1044 & 811 & 46.93 & ws & 11884 & 135.20 & cgt \\
11 & 920 & 726 & 54.21 & ws & 16461 & 118.49 & cgt \\
12 & 942 & 741 & 47.65 & ws & 11468 & 113.20 & cgt \\
13 & 966 & 758 & 49.57 & ws & 13112 & 150.16 & cgt \\
14 & 889 & 704 & 42.60 & ws & 13597 & 116.41 & cgt \\
15 & 1020 & 795 & 45.52 & ws & 8350 & 78.28 & st \\
16 & 987 & 772 & 57.55 & ws & 16608 & 146.78 & cgt \\
17 & 1034 & 805 & 58.57 & ws & 12619 & 150.77 & cgt \\
18 & 899 & 711 & 50.71 & ws & 16965 & 149.08 & cgt \\
19 & 933 & 734 & 51.57 & ws & 15444 & 134.99 & cgt \\
20 & 1015 & 792 & 61.64 & ws & 13101 & 154.82 & cgt \\
21 & 925 & 729 & 54.53 & ws & 17059 & 138.16 & cgt \\
22 & 888 & 703 & 51.29 & ws & 7929 & 68.12 & st \\
23 & 976 & 765 & 49.75 & ws & 15160 & 139.96 & cgt
\end{tabular}

to be continued continua 
KELLER, A. et al. Wood properties of Myracrodruon urundeuva.

continuation - Table 3

continuação - Tabela 3

\begin{tabular}{cccccccc}
\hline Sample & $\rho_{12}{ }^{(1)}$ & $\rho_{\text {bas }}{ }^{(2)}$ & $\mathrm{f}_{\mathrm{c0}}{ }^{(3)}$ & $\mathrm{Ftc}^{(4)}$ & $\mathrm{MOE}^{(5)}$ & $\mathrm{MOR}^{(6)}$ & $\mathrm{Ftr}^{(7)}$ \\
\hline 24 & 911 & 719 & 49.54 & ws & 11168 & 103.50 & cgt \\
25 & 919 & 725 & 45.71 & ws & 13490 & 105.86 & cgt \\
26 & 991 & 775 & 53.36 & ws & 14257 & 129.51 & cgt \\
27 & 934 & 735 & 50.80 & ws & 15765 & 135.88 & cgt \\
28 & 1026 & 799 & 58.06 & ws & 12735 & 108.77 & cgt \\
29 & 1060 & 823 & 62,02 & ws & 10771 & 110.94 & cgt \\
30 & 1054 & 818 & 68.88 & ws & 12030 & 154.17 & cgt \\
31 & 954 & 750 & 45.87 & s & 8967 & 103.46 & st \\
32 & 893 & 706 & 40.75 & ws & 10914 & 102.98 & cgt \\
33 & 1004 & 784 & 56.99 & ws & 12456 & 130.99 & cgt \\
34 & 1045 & 812 & 52.44 & ws & 11784 & 133.17 & cgt \\
35 & 1155 & 887 & 68.38 & ws & 12958 & 130.52 & cgt \\
36 & 1171 & 897 & 73.17 & ws & 13878 & 155.79 & cgt \\
\hline Mean & 984 & 770 & 53.84 & & 12632 & 123.58 & \\
\hline
\end{tabular}

(1) $\rho_{12}=$ apparent density at $12 \%$ moisture content; (2) $\rho_{\mathrm{bas}}=$ basic density; (3) $\mathrm{f}_{\mathrm{c} 0}=$ compression parallel to the grain; (4) Ftc = failure types in compression; (5) $\mathrm{MOE}=$ modulus of elasticity (bending); (6) MOR = modulus of rupture; (7) $\mathrm{Ftr}=$ failure types static in bending. $\mathrm{Ft}=$ failure types; ws = wedge split; $\mathrm{c}=$ crushing; $\mathrm{s}=$ shearing; $\mathrm{cgt}=\mathrm{cross}$-grain tension; st = splintering tension;

(1) $\rho_{12}=$ densidade aparente a $12 \%$ de teor de umidade; (2) $\rho_{\mathrm{bas}}=$ densidade básica; (3) $\mathrm{f}_{\mathrm{c} 0}=$ compressão paralela às fibras; (4) Ftc = tipos de ruptura na compressão; (5) MOE = módulo de elasticidade (flexão); (6) MOR = módulo de ruptura; (7) $\mathrm{Ftr}=$ tipos de ruptura estáticos na flexão. Ft = tipos de ruptura; ws = fenda em cunha; c = esmagamento; $\mathrm{s}=$ compressão com cisalhamento; cgt = tração desviada - grã cruzada; st = tração com desfibramento.

The mean basic density was $770 \mathrm{~kg} \cdot \mathrm{m}^{-3}$, while the density at $12 \%$ moisture $\left(\rho_{12}\right)$ was $984 \mathrm{~kg} \cdot \mathrm{m}^{-3}$. Density is influenced by anatomical variations, and these, in turn, vary according to age, axial and radial positions, spacing between trees, climatic and soil conditions. Thus, comparing density values with other studies, we noticed some variations. For example, Tung et al. (2011), studying M. urundeuva at the age of 20 years, also cultivated in a homogeneous plantation (spacing $3 \mathrm{~m}$ x $3 \mathrm{~m}$ ), in Selvíria, Mato Grosso do Sul, reported a basic density of $750 \mathrm{~kg} \cdot \mathrm{m}^{-3}$, lower than the present value. However, climatic and spacing diferences $(3 \mathrm{~m} \times 2 \mathrm{~m}$ in our study) between plantations could account for this. Lisboa et al. (2016) studied M. urundeuva wood for plywood production, and trees were collected in a natural cerrado area in the southwest of Goiás state. Although no information is provided about age, these trees had, on average, $11.6 \mathrm{~cm}$ in $\mathrm{DBH}$, height $28 \mathrm{~m}$ and basic density of $820 \mathrm{~kg} . \mathrm{m}^{-3}$. Thus, these trees had greater height and smaller diameter than those of the present study (Table 1). Palharini et al. (2014) reported basic density of $863 \mathrm{~kg} \cdot \mathrm{m}^{-3}$ in M. urundeuva samples collected in the City of Santa Luz, Piauí state, but, again, the age of trees was not mentioned. In these last two studies, the density was higher than our mean value $\left(770 \mathrm{~kg} \cdot \mathrm{m}^{-3}\right)$

Mainieri and Chimelo (1989) and Lorenzi (1992) reported a mean density at $15 \% \mathrm{MC}$ of $1,190 \mathrm{~kg} \cdot \mathrm{m}^{-3}\left(905 \mathrm{~kg} \cdot \mathrm{m}^{-3}\right.$ when the value is converted to the base of basic density), but without age, spacing or sampling area data. The much higher values suggest that the trees were older than those of the present study.

According to Finger and Logsdon (2004), the values of apparent density and basic density allow the identification, in a simplified way, of species into one of the resistance classes, as defined by NBR 7190/97 (ABNT, 1997), and allow estimation of wood quality for structural use. Accordingly, this basic density value allowed us to categorize $M$. urundeuva wood into resistance class C40 (basic density higher than $750 \mathrm{~kg} \cdot \mathrm{m}^{-3}$ ), i.e., medium to high mechanical resistance, which is indicated for use in medium-sized structures. 
Characterization of rupture type, performed according to ASTM D143/94 (ASTM, 2007), indicated that "wedge split" type represented more than $94 \%$ of the samples, without rejecting any results obtained and indicating the homogeneity and regular pattern of sample rupture. The wedge split rupture is considered regular and quite common in compression tests.

The average value of compression parallel to the grain was $53.84 \mathrm{MPa}$. This value is lower than that presented by Mainieri and Chimelo (1989) of $90.0 \mathrm{MPa}$; however, the age and planting conditions were not mentioned. Then, based on our results, the wood of M. urundeuva could be classified into structural class C40 - hardwood ( $\left.\mathrm{f}_{\mathrm{c} 0, \mathrm{k}} \geq 40 \mathrm{MPa}\right)$, evidencing the good mechanical performance of the species at 20 years old. The results indicate that $M$. urundeuva wood can be used in wood structures, since this result puts it in the higher strength classes, as defined by NBR 7190 (ABNT, 1997) for hardwoods (Table 2).

The mean value of MOE, $12632 \mathrm{MPa}$, is lower than that available in the NBR 7190 table (ABNT, 1997), which presents $23393 \mathrm{MPa}$. However, like compressive strength, age and tree occurrence are different in the two studies. The mean value of MOR was $123.58 \mathrm{MPa}$. Longui et al. (unpublished data) determined some properties of 20-year-old $M$. urundeuva grown in two types of agrosilvopastoral system which reported MOE between 9722 - $9900 \mathrm{MPa}$ and MOR between 105.5 and $110.9 \mathrm{MPa}$, lower values than those in the present study. In this case, other factors, such as seed origin and climatic and soil conditions, could have influenced the results. Therefore, both MOE and MOR values allow us to again classify 20-year-old $M$. urundeuva wood into the C40 strength class, among the resistance classes defined by NBR 7190 (ABNT, 1997) for hardwoods.

The types of rupture found did not lead to rejection of any results. The cross-grain tension type represented more than $91 \%$ of the samples, indicating homogeneity and the normal pattern of rupture. Cross-grain tension rupture is characteristic of trees that present growth stresses or samples of juvenile wood near the pith. Our samples come from relatively young M. urundeuva trees with smaller diameter compared to older trees.
We highlight that these results come from 20-year-old trees, which are relatively young for the species and can grow for many decades. According to Nogueira (2010), older trees reach up to $30 \mathrm{~m}$ in high and $1 \mathrm{~m}$ in diameter. Therefore, the species cultivated in homogeneous plantations can provide quality wood in a relatively short time. However, tree spacing and edaphoclimatic conditions will influence heartwood and sapwood percentage and wood density. In addition, after cutting, some trees presented regrowth, which provides continuity in wood exploitation, potentially with different uses than originally planned. Thus, thinning could be partial, obtaining materials with different ages.

Our average values of shrinkage (Table 4) in trees with mean DBH of $23.2 \mathrm{~cm}$ were $0.62 \%$ for longitudinal shrinkage, $7.32 \%$ tangential, $4.51 \%$ radial, $13.64 \%$ volumetric shrinkage and 1.69 anisotropy coefficient. Guimarães Júnior et al. (2016), in a study with different diameter classes (5-12; 12-18.9 and 25.9-32.9 cm) in M. urundeuva collected in a Deciduous Seasonal Forest, in the municipality of Jataí, Goiás state, found values of 10.34, 11.16 and $5.82 \%$ for tangential shrinkage; 6.45 , 7.41 and $3.99 \%$ for radial shrinkage; 16.30, 14.78 and $9.46 \%$ for volumetric shrinkage and 1.65 , 1.50 and 1.49 for anisotropy coefficient. Palharini et al. (2014), in samples of M. urundeuva at different commercial heights, collected in the municipality of Santa Luz, Piauí state, reported a mean tangential shrinkage of $8.67 \%$, mean radial shrinkage of $5.36 \%$ and anisotropy coefficient of 1.62 . The age of the trees was not mentioned in either of these two studies, and the results were established by Brazilian standard NBR 7190 (ABNT, 1997). Our values were higher compared to the largest diameter class of Guimarães Júnior et al. (2016), the class closest to our diameter classes, except for the value of anisotropy coefficient, which was lower in our study. Our values of tangential and radial shrinkage were lower, while our anisotropy coefficient values were higher compared to Palharini et al. (2014). 
KELLER, A. et al. Wood properties of Myracrodruon urundeuva.

Table 4. Shrinkage values (\%) and anisotropy coefficient from green to oven-dry moisture content of 20-year-old Myracrodruon urundeuva wood.

Tabela 4. Valores de retração (\%) e coeficiente de anisotropia do teor de umidade verde ao seco em estufa da madeira de Myracrodruon urundeuva aos 20 anos de idade.

\begin{tabular}{|c|c|c|c|c|c|}
\hline Sample & Longitudinal & Tangential & Radial & Volumetric & Anisotropy coefficient \\
\hline 1 & 0.71 & 5.47 & 2.80 & 9.61 & 1.95 \\
\hline 2 & 0.77 & 6.38 & 5.15 & 13.49 & 1.24 \\
\hline 3 & 0.36 & 9.45 & 5.85 & 17.71 & 1.62 \\
\hline 4 & -0.02 & 9.74 & 4.20 & 15.62 & 2.32 \\
\hline 5 & 0.95 & 6.28 & 3.59 & 11.74 & 1.75 \\
\hline 6 & 0.83 & 7.25 & 5.29 & 14.78 & 1.37 \\
\hline 7 & 0.33 & 5.57 & 3.17 & 9.73 & 1.76 \\
\hline 8 & 0.10 & 8.49 & 5.13 & 15.30 & 1.65 \\
\hline 9 & 0.53 & 7.42 & 5.01 & 14.32 & 1.48 \\
\hline 10 & 1.06 & 9.11 & 4.73 & 16.71 & 1.93 \\
\hline 11 & 0.41 & 8.60 & 5.17 & 15.84 & 1.66 \\
\hline 12 & 0.48 & 7.68 & 4.69 & 14.20 & 1.64 \\
\hline 13 & 0.70 & 6.24 & 2.65 & 10.32 & 2.35 \\
\hline 14 & 0.91 & 6.05 & 3.95 & 11.83 & 1.53 \\
\hline 15 & 0.93 & 8.97 & 9.42 & 22.42 & 0.95 \\
\hline 16 & ---- & 9.81 & 5.94 & & 1.65 \\
\hline 17 & 0.82 & 6.41 & 3.07 & 11.14 & 2.09 \\
\hline 18 & 0.62 & 7.69 & 4.15 & 13.72 & 1.85 \\
\hline 19 & 0.51 & 8.30 & 5.40 & 15.87 & 1.54 \\
\hline 20 & 0.45 & 8.04 & 4.26 & 14.10 & 1.89 \\
\hline 21 & 0.20 & 9.03 & 5.94 & 17.10 & 1.52 \\
\hline 22 & 0.30 & 6.06 & 3,27 & 10.38 & 1.85 \\
\hline 23 & 0.37 & 9.54 & 5.64 & 17.59 & 1.69 \\
\hline 24 & 0.66 & 5.56 & 3.38 & 10.32 & 1.64 \\
\hline 25 & 1.22 & 7.50 & 3.75 & 13.71 & 2.00 \\
\hline 26 & 0.53 & 8.76 & 4.26 & 15.09 & 2.06 \\
\hline 27 & 0.38 & 9.55 & 5.20 & 17.07 & 1.84 \\
\hline
\end{tabular}

to be continued continua 
KELLER, A. et al. Wood properties of Myracrodruon urundeuva.

continuation - Table 4

continuação - Tabela 4

\begin{tabular}{cccccc}
\hline Sample & Longitudinal & Tangential & Radial & Volumetric & Anisotropy coefficient \\
\hline 28 & 1.36 & 4.96 & 3.74 & 10.81 & 1.33 \\
29 & 0.57 & 7.24 & 3.71 & 12.60 & 1.95 \\
30 & 0.49 & 4.57 & 3.20 & 8.78 & 1.43 \\
31 & 0.76 & 4.82 & 7.25 & 14.14 & 0.66 \\
32 & 1.01 & 5.86 & 3.71 & 11.45 & 1.58 \\
33 & 0.91 & 7.25 & 3.48 & 12.72 & 2.08 \\
34 & 0.60 & 8.95 & 4.89 & 16.18 & 1.83 \\
35 & 0.56 & 6.61 & 3.31 & 11.36 & 2.00 \\
36 & 0.48 & 4.44 & 4.06 & 9.60 & 1.09 \\
\hline Mean & 0.62 & 7.32 & 4.51 & 13.64 & 1.69 \\
\hline
\end{tabular}

The study of wood shrinkage is essential to determine use since pieces that must be embedded or need precision should not present great variation in their dimensions. According to Silva (2002), values between 1.2 - 1.5 are considered excellent, between 1.5 - 2.0 are regular, and above 2.0 are bad. However, the anisotropic factor, taken alone, does not characterize a wood as being stable, causing, instead, a false impression of stability (Potulski, 2010). Ideally, wood should present anisotropy coefficient as close to the unit as possible and low volumetric shrinkage.

The anisotropy coefficient, as defined by the relationship between tangential and radial shrinkage (T/R) of $M$. urundeuva in the present study, was 1.69 (mean of the 36 test specimens). The strength values obtained allow us to state that $M$. urundeuva wood is indicated for structures, in general, and building fine furniture, boats, musical instruments, and sports equipment, among others. Lucena et al. (2011) emphasize the use of wood for building fences and as fuel in northeastern Brazil.
The basic density and the apparent density were positively related to the compression parallel to the grain and MOR (Figure 2). Usually, mechanical properties tend to be related to wood density (Zhang, 1994). For this reason, wood density is often used to predict mechanical properties (Hoadley, 2000). Based on the studies of other groups, we emphasize the trend whereby density (physical property) increases with age in Brazilian native woods (Longui et al., 2010; Lima et al., 2011; Longui et al., 2014), which, consequently, will influence the mechanical properties, especially when we compare the regions near the pith with those close to the bark. On the other hand, Zhang (1995) compared hard- and softwoods and reported that the physico-mechanical properties in the hardwoods studied were remarkably less influenced by growth rate. The author further reported that growth rate has a significant effect on mechanical properties which can be attributed to wood density. Thus, the values of mechanical properties tend to increase as M. urundeuva trees grow. 

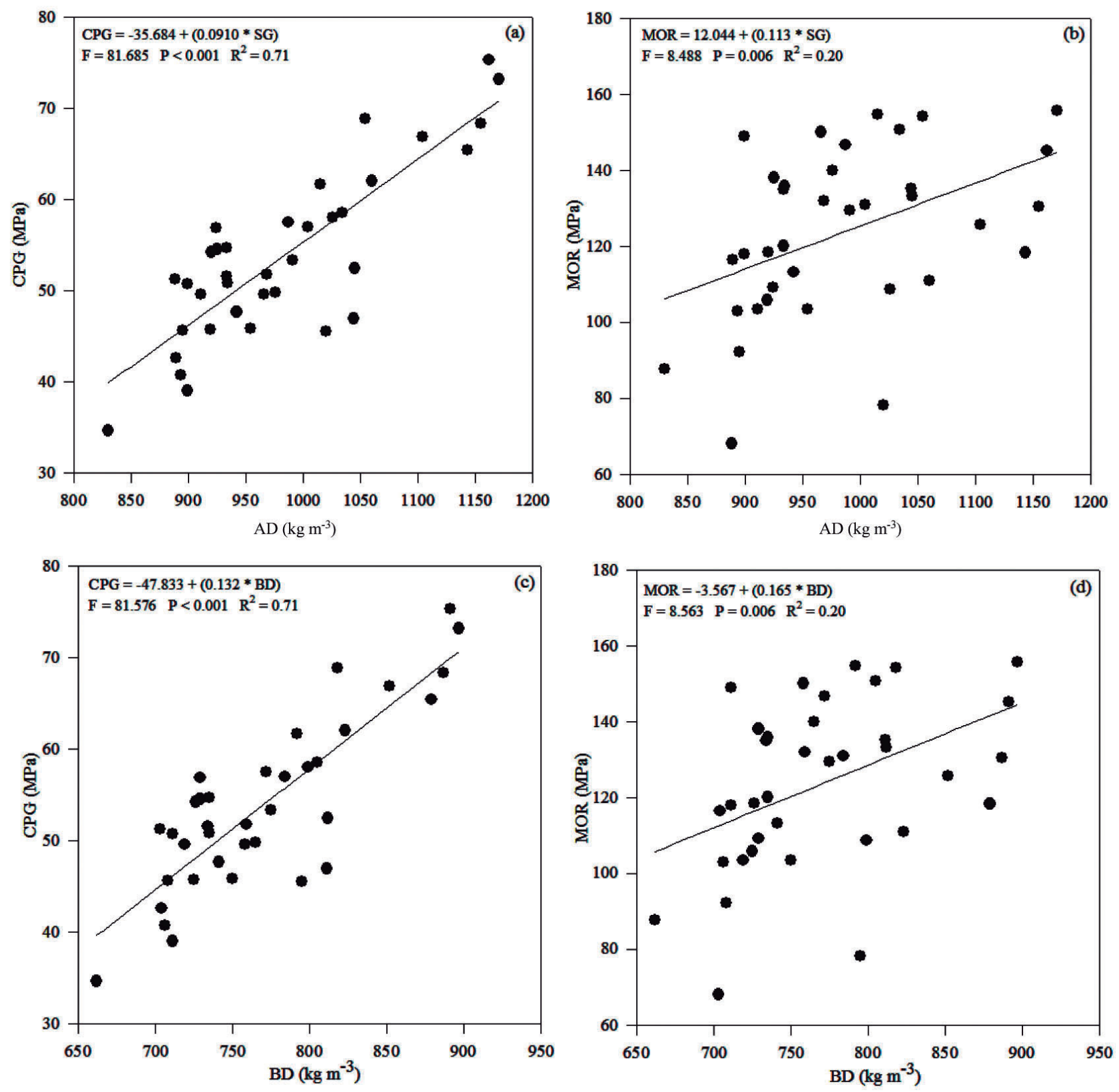

Figure 2. Relationships among properties of Myracrodruon urundeuva wood. a) Compression parallel to grain (CPG) as a function of apparent density (AD). b) Modulus of rupture (MOR) as a function of apparent density (AD). c) Compression parallel to grain (CPG) as a function of basic density (BD). d) Modulus of rupture (MOR) as a function of basic density (BD).

Figura 2. Relações entre propriedades da madeira de Myracrodruon urundeuva. a) Compressão paralela à grã (CPG) em função da densidade aparente (AD). b) Módulo de ruptura (MOR) em função da densidade aparente (AD). c) Compressão paralela à grã (CPG) em função da densidade básica (BD). d) Módulo de ruptura (MOR) em função da densidade básica (BD). 


\section{CONCLUSIONS}

Basic density was $770 \mathrm{~kg} \mathrm{~m}^{-3}$, and apparent density at EMC was $984 \mathrm{~kg} \mathrm{~m}^{-3}$. The anisotropy coefficient of 1.69 is considered "regular", indicating that wood can be used in the manufacture of fine furniture, frames, boats, musical instruments, or sports equipment. The wood presented good mechanical behavior, with an average strength for parallel compression of $53.84 \mathrm{MPa}, \mathrm{MOE}$ of $12632 \mathrm{MPa}$ and MOR of 123.58 MPa. Mechanical properties were identified as class 40, which shows the potential for use in medium-sized structures and construction. Basic density and specific gravity correlate positively with compression parallel to the grain and MOR. Wood quality, a positive characteristic, added to good technology, even in young trees, shows that values of physical and mechanical properties are suitable for various uses when compared to the values of older trees. Overall, our results confirmed that this homogeneous planting was adequate to obtain $M$. urundeuva wood with such quality, thus maintaining the sustainability of native stands.

\section{ACKNOWLEDGMENTS}

The authors thank Israel Luiz de Lima for fieldwork (Forestry Institute - IF), as well as Ailton de Lima Lucas (UNESP - Botucatu) for laboratory assistance.

\section{REFERENCES}

AMERICAN SOCIETY FOR TESTING AND MATERIALS - ASTM. D143-94: standard test methods for small clear specimens of timber. West Conshohocken, 2007. 31 p.
ASSOCIAÇÃO BRASILEIRA DE NORMAS TÉCNICAS - ABNT. NBR 7190: projeto de estruturas de madeira. Rio de Janeiro, 1997. 107 p.

CARVALHO, P.E.R. Espécies arbóreas brasileiras. Brasília, DF: Embrapa, 2003. 1040 p.

CENTRO DE PESQUISAS METEOROLÓGICAS E CLIMÁTICAS APLICADAS À AGRICULTURACEPAGRI. Clima dos municípios paulistas. Available at: <http://www.cpa.unicamp.br/ outrasinformacoes/clima-dos-municipios-paulistas. html>. Access on: 15 July 2017.

EUFRADE JUNIOR, H.J. et al. Potential of rubberwood (Hevea brasiliensis) for structural use after the period of latex extraction: a case study in Brazil. Journal of Wood Science, v. 61, n. 4, p. 384-390, 2015.

FINGER, Z.; LOGSDON, N. B. Caracterização preliminar da madeira de pau-de-bálsamo, Myroxylon peruiferum L. f. In: ENCONTRO BRASILEIRO EM MADEIRAS E EM ESTRUTURAS DE MADEIRA, 9., 2004, Cuiabá. Anais... Cuiabá: Ibramem, 2004. 11 p.

GUIMARÃES JUNIOR, J.B. et al. Caracterização tecnológica da madeira de Myracrodruon urundeuva em diferentes classes diamétricas. Enciclopédia Biosfera, Centro Científico Conhecer, v. 13, n. 24, 250-261, 2016.

HERINGER, E.P.; FERREIRA, M.B. Árvores úteis da região geoeconômica do D.F.: aroeira, gonçalo e gibatão: o gênero Astronium e sua importância florestal. Cerrado, v.s. n. 2, p. 24-33, 1973.

HOADLEY, B. Understanding wood: a craftsman's guide to wood technology. Newtown: Taunton Press, 2000. 280 p. 
INSTITUTO BRASILEIRO DO MEIO AMBIENTE E DOS RECURSOS NATURAIS RENOVÁVEIS IBAMA. Portaria normativa n. ${ }^{\circ} 83$, de 26/09/1991. Available at: <http://www.ibama.gov.br/documentos/ portaria-83n>. Access on: 5 March 2017.

LIMA, I.L. et al. Densidade básica e dimensões celulares da madeira de Balfourodendron riedelianum em função da procedência e posição radial. Revista do Instituto Florestal, v. 23, n. 2, p. 217-230, 2011.

LISBOA, F.J.N. et al. Potencial de utilização da madeira de Sclerolobium paniculatum, Myracrodruon urundeuva e Amburana cearensis para produção de compensados. Scientia Forestalis, v. 44, n. 109, p. 129-139, 2016.

LONGUI, E.L. et al. Correlações entre algumas propriedades físicas, características químicas e anatômicas da madeira de Luehea divaricata Mart. Malvaceae (Tiliaceae). Revista do Instituto Florestal, v. 22, n. 2, p. 177-187, 2010.

et al. Radial variation of wood anatomy and basic density of Anadenanthera colubrina (Vell.) Brenan. Revista do Instituto Florestal, v. 26, n. 2, p. 193-201, 2014.

LORENZI, H. Árvores brasileiras: manual de identificação e cultivo de plantas arbóreas nativas do Brasil. Nova Odessa: Plantarum, 1992. v. 1, 352 p.

Árvores brasileiras: manual de identificação e cultivo de plantas arbóreas do Brasil. 2. ed. Nova Odessa: Plantarum, 2002. 368 p.

LUCENA et al. Uso e conhecimento da aroeira (Myracrodruon urundeuva) por comunidades tradicionais no Semiárido brasileiro.

Sitientibus série Ciências Biológicas, v. 11, n. 2, p. 255-264, 2011.
MAINIERI, C.; CHIMELO, J.P. Fichas de características das madeiras brasileiras. São Paulo: Instituto de Pesquisas Tecnológicas do Estado de São Paulo - IPT, 1989. 418 p. (IPT Publicação, 1791).

NAHUZ, M.A.R. et al. Catálogo de madeiras brasileiras para a construção civil. São Paulo: Instituto de Pesquisas Tecnológicas do Estado de São Paulo - IPT, 2013. 103 p. (Publicação IPT, 4371).

NOGUEIRA, J.C.B. Reflorestamento misto com essências nativas: a mata ciliar. São Paulo: Instituto Florestal, 2010. 147 p.

PALHARINI, K.M.Z. et al. Avaliação das propriedades físicas em madeiras de Croton celtidifolius e Myracrodruon urundeuva. Enciclopédia Biosfera, Centro Científico Conhecer, v. 10, n. 19, p. 2982-2989, 2014.

POTULSKI, D.C. Densidade e retratibilidade da madeira juvenil de Pinus maximinoi H. e. Moore e Pinus taeda L. 2010. 48 f. Dissertação (Mestrado em Engenharia Florestal) - Universidade Federal do Paraná, Curitiba.

SILVA, J.C. Caracterização da madeira de Eucalyptus grandis Hill ex Maiden, de diferentes idades, visando a sua utilização na indústria moveleira. 2002. 160 f. Tese (Doutorado em Engenharia Florestal) - Universidade Federal do Paraná, Curitiba.

SILVA-LUZ, C.L.; PIRANI, J.R. Anacardiaceae. In: LISTA de espécies da flora do Brasil. Jardim Botânico do Rio de Janeiro, 2017. Available at: Access on: February 2017.

TUNG, E.S.C. et al. Variação, divergência e correlações genéticas entre caracteres silviculturais e densidade básica da madeira em progênies de Myracrodruon urundeuva (Engler) Fr. Allem. Revista do Instituto Florestal, v. 23, n. 1, p. 1-12, 2011. 
KELLER, A. et al. Wood properties of Myracrodruon urundeuva.

ZHANG, S.Y. Mechanical-properties in relation to specific-gravity in 342 Chinese woods. Wood and Fiber Science, v. 26, n. 4, p. 512-526, 1994.

. Effect of growth rate on wood specific gravity and selected mechanical properties in individual species from distinct wood categories. Wood Science and Technology, v. 29, n. 6, p. 451-465, 1995. 